\title{
EFEKTIVITAS INTERVENSI PSIKOEDUKASI TERHADAP TINGKAT KECEMASAN KELUARGA DALAM MERAWAT KLIEN SKIZOFRENIA
}

\author{
EFFECTIVENESS OF PSYCHOEDUCATION INTERVENTIONS ON FAMILY \\ ANXIETY LEVELS IN CARING FOR SCHIZOPHRENIC CLIENTS
}

\author{
Tantan Hadiansyah ${ }^{1}$, Aat Sriati Aulia ${ }^{2}$, Iskandarsyah ${ }^{3}$ \\ Fakultas Keperawatan ${ }^{1 \& 2}$, Fakultas Psikologi ${ }^{3}$, Universitas Padjadjaran \\ Email: tantan.hadiansyah78@gmail.com
}

\begin{abstract}
ABSTRAK
Pendahuluan: Prevalensi kecemasan pada keluarga dengan penderita skizofrenia menunjukkan angka yang cukup tinggi dibandingkan dengan keluarga yang merawat penyakit kronis lainnya. Pada keluarga dengan skizofrenia, kecemasan merupakan masalah psikologis yang muncul sebagai reaksi terhadap beban ekonomi dan perawatan yang tinggi, beban psikologis keluarga, penurunan kualitas hidup anak dan keluarga, serta dukungan sosial yang berkurang. Kecemasan terjadi ketika seseorang mengalami kesulitan menghadapi situasi, masalah dan tujuan hidup. Tujuan : penelitian ini adalah untuk mengetahui efektivitas intervensi psikoedukasi terhadap tingkat kecemasan keluarga dalam merawat klien skizofrenia. Metode: Penelitian ini menggunakan quasi eksperiment dengan pretest and post test with control group desain. Populasi penelitian ini sebanyak 75 responden. Sampel yang digunakan sebanyak 24 responden, dibagi menjadi 2 kelompok, yaitu 12 responden kelompok intervensi dan 12 responden kelompok kontrol. Kelompok intervensi mendapatkan psikoedukasi sebanyak 5 sesi, sedangkan kelompok kontrol tidak diberikan intervensi. Tingkat kecemasan diukur dengan menggunakan Zung's Self rating anxiety scale. Sampel diambil menggunakan consecutive sampling technique sesuai dengan kriteria inklusi dan ekslusi. Data dianalisis menggunakan uji $t$ berpasangan. Hasil: menunjukkan bahwa terdapat perbedaan rata-rata kecemasan postintervensi, rata-rata kelompok intervensi sebesar 48,9167 dan rata-rata kelompok kontrol sebesar 54,6667, sehingga dapat disimpulkan bahwa ratarata tingkat kecemasan kelompok intervensi lebih kecil 5,75 dibandingkan dengan kelompok control ( $p$-value=0,007). Diskusi: Hasil ini menunjukkan bahwa psikoedukasi efektif dalam menurunkan tingkat kecemasan keluarga dalam merawat klien skizofrenia, sehingga dapat diterapkan dalam menangani masalah psikososial yang dialami oleh keluarga klien skizofrenia.
\end{abstract}

Kata kunci : Kecemasan, Keluarga, Psikoedukasi, Skizofrenia

\begin{abstract}
Introduction: The prevalence of anxiety in families with schizophrenia show a fairly high figure compared to families with other chronic diseases. In families with schizophrenia, Anxiety is a psychological problem that emerged in reaction to economic burden and high cost of care, psychological burden of the family, loss of quality of life of children and families, as well as reduce social support. Anxiety occurs when someone has difficulty in coping with the situation, problems and goals. Purpose: The purpose of this study was to determine the effectiveness of psychoeducation intervention on the anxiety level of the family in caring schizophrenia. Method: This study used a quasiexperiment with pretest and post-test with control group design. The population of this study was 75 respondens. The sample were divided into intervention and control group with 12 respondents respectively. The intervention group received psychoeducation for five sessions, while the control group did not received intervention. The level of anxiety was measured using the Zung's Self Rating Anxiety Scale. Samples were taken using a Consecutive Sampling in accordance with the inclusion and exclusion criteria. Data were analyzed using paired t test. Results: The result showed that the average level of anxiety of intervention group was 48.9167, while average
\end{abstract}

JURNAL

SKOLASTIK KEPERAWATAN

Vol, 4, No. 2 Juli - Desember 2018

ISSN: $2443-0935$ E-ISSN 2443 - 16990 
level of anxiety of control group was 54.6667, which was statistically significant difference between intervention group and control group on the average of the level of anxiety ( $p$-value $=.007$ ). Discussion: Therefore, the result can be concluded that the average level of anxiety of intervention group was smaller by 5.75 than control group. The result indicates that psychoeducation is effective to lowering anxiety levels of the family in caring schizophrenia, so that it can be applied in dealing the family psychosocial issue of clients with schizophrenia.

Key words: anxiety, family, psychoeducation, schizophrenia

\section{PENDAHULUAN}

Skizofrenia adalah suatu penyakit otak persisten dan serius yang mengakibatkan perilaku psikotik, pemikiran konkrit, dan kesulitan dalam memproses informasi, hubungan interpersonal, serta memecahkan masalah (Stuart, 2005). Ahli lain mengatakan bahwa Skizophrenia adalah gangguan psikotik yang kronik, pada orang yang mengalaminya tidak dapat menilai realitas dengan baik dan pemahaman diri yang buruk (Kaplan \& Sadock, 2007).

Sebagai salah satu bentuk ganguan jiwa Skizofrenia merupakan gangguan psikotik yang paling sering, hampir $1 \%$ penduduk dunia menderita psikotik selama hidup mereka di Amerika. Skizofrenia lebih sering terjadi pada negara industri dan terdapat lebih banyak pada populasi urban dan kelompok sosial ekonomi rendah, bahkan di dunia mencapai lebih dari 21 juta jiwa menderita gangguan jiwa berat (WHO, 2014).

Skizofenia akan menimbulkan penderitaan yang mendalam bagi individu dan beban yang berat bagi keluarga, baik beban mental maupun materil karena gangguan menjadi kronis dan individu tidak mampu lagi produktif sehingga memerlukan perawatan dan tanggung jawab sepanjang masa oleh keluarganya. Perawatan dan tanggung jawab ini membutuhkan waktu, tenaga dan biaya yang tidak sedikit dan dapat menimbulkan beban bagi keluarga. Beban tersebut berkaitan dengan masalah objektif dan subjektif yang berdampak terhadap peran, tanggung jawab dan hubungan yang diharapkan oleh keluarga sebagai caregiver.

Keluarga merupakan sebuah sistem terbuka, yang berarti suatu perubahan atau gangguan pada salah satu bagian dari sistem tersebut dapat mengakibatkan perubahan atau gangguan pada seluruh sistem. Hal ini berarti, saat salah satu anggota keluarga menderita skizofrenia, maka seluruh keluarga ikut merasakan dampak negatifnya. Keluarga umumnya mengalami perasaan sedih, cemas, ketakutan, khawatir dan kebingungan menghadapi anggota keluarganya yang mengalami skizofrenia (Goode, 2007).

Perhatian penelitian kesehatan pada saat ini lebih fokus pada klien penderita skizofrenia, sedangkan keluarga yang selalu dekat dengan klien dan memberikan perawatan serta dukungan emosional masih sedikit dilakukan penelitian. Hal ini disebabkan di Indonesia masih terbatasnya akses literatur dan jurnal 
terpublikasi mengenai pengalaman dan masalah yang dihadapi keluarga dalam merawat klien. Perhatian pada keluarga ini menjadi hal yang sangat penting karena keberhasilan pengobatan dan perawatan klien tidak terlepas dari bantuan dan dukungan yang diberikan. Hal ini didukung oleh penelitian yang dilakukan oleh Reinhard, Given, Petlick, dan Bemis (2008) bahwa informasi tentang fluktuatif kondisi klien, tanda dan gejala, serta respon klien akan pengobatan yang dijalani hanya bisa didapatkan dari keluarga yang merawatnya.

Menurut Comer (1992) dalam Videbeck (2008) kecemasan merupakan masalah psikososial yang sering terjadi pada setiap orang. Pada keluarga dengan skizofrenia, masalah psikososial kecemasan muncul sebagai reaksi dari stress akibat beban ekonomi dan perawatan yang tinggi, beban psikologis keluarga, penurunan kualitas hidup anak dan keluarga, serta dukungan sosial yang berkurang. Kecemasan adalah perasaan takut yang tidak jelas dan tidak didukung oleh situasi. Kecemasan terjadi ketika seseorang mengalami kesulitan menghadapi situasi, masalah dan tujuan hidup.

Tingkat kecemasan yang dialami oleh keluarga dalam merawat klien skizofrenia dengan keluarga yang merawat klien dengan penyakit kronis, menunjukkan bahwa tingkat kecemasan pada keluarga dengan skizofrenia lebih tinggi dibandingkan dengan tingkat kecemasan keluarga dengan penyakit kronis lainnya. Pendapat tersebut merupakan hasil penelitian yang berjudul Anxiety disorders in Family with schizophrenia: prevalence and impact on the subjective quality of life (Braga, Medlowicz, dan Marrocos, 2010).

Tabel 1 Laporan Data Kesehatan Jiwa Kota Cimahi

\begin{tabular}{|l|l|l|l|}
\hline No & Puskesmas & $\begin{array}{l}\text { Jumlah } \\
\text { Penderita } \\
\text { Skizofrenia }\end{array}$ & Persentase \\
\hline 1 & $\begin{array}{l}\text { Melong } \\
\text { Asih }\end{array}$ & 75 & 22,12 \\
\hline 2 & $\begin{array}{l}\text { Cimahi } \\
\text { Tengah }\end{array}$ & 41 & 12,09 \\
\hline 3 & $\begin{array}{l}\text { Cigugur } \\
\text { Tengah }\end{array}$ & 41 & 12,09 \\
\hline 4 & Cibeureum & 36 & 10,62 \\
\hline 5 & $\begin{array}{l}\text { Cimahi } \\
\text { Utara }\end{array}$ & 33 & 9,73 \\
\hline 6 & Cibeber & 28 & 8,26 \\
\hline 7 & Cipageran & 24 & 7,08 \\
\hline 8 & $\begin{array}{l}\text { Cimahi } \\
\text { Selatan }\end{array}$ & 19 & 5,60 \\
\hline 9 & $\begin{array}{l}\text { Melong } \\
\text { tengah }\end{array}$ & 15 & 4,42 \\
\hline 10 & Pasirkaliki & 11 & 3,24 \\
\hline 11 & Citeureup & 11 & 3,24 \\
\hline 12 & Padasuka & 5 & 1,47 \\
\hline Jumlah & 339 & 100,00 \\
\hline
\end{tabular}

Sumber: Dinas Kesehatan Kota Cimahi 2015

Kondisi kecemasan pada keluarga jika tidak ditangani akan memberikan dampak yang tidak hanya dirasakan oleh klien tetapi dirasakan oleh keluarga secara langsung. Dampak yang ditimbulkan oleh kecemasan adalah ketidaknyamanan kognitif, psikomotor dan respon fisiologis, seperti kesulitan berpikir logis, tremor, dan peningkatan tanda-tanda vital. Sehingga dapat mengakibatkan penurunan kemampuan pada individu dan keluarga (Videbeck, 2008). Sedangkan menurut Takai et al (2011) dampak yang diterima oleh keluarga adalah penurunan kualitas hidup, sehingga akan mempengaruhi kondisi kesehatan jiwa bahkan 
sampai mengalami gangguan mental.sehingga dapat menimbulkan terjadinya kekambuhan dan kembali dirawat.

Penanganan yang harus dilakukan terhadap kecemasan keluarga diperlukan adanya keterlibatan peran perawat. Perawat adalah salah satu profesi yang ikut bertanggung jawab dalam menangani masalah psikologis yang dialami keluarga, pada waktu yang akan datang tidak menjadi penyebab gangguan kejiwaan. Tindakan penanganan secara awal inilah yang dapat dilakukan untuk mencegah terjadinya gangguan jiwa terkait peran keluarga dalam merawat klien skizofrenia. Peran yang dapat dilakukan oleh perawat jiwa untuk mengatasi masalah pada keluarga saat ini telah dikembangkan psikoterapi untuk keluarga antara lain Family Psycoeducation (FPE) dan Triangle Therapy (Keliat \& Walter,2011). Selain terapi tersebut, terdapat terapi modalitas yang dapat digunakan untuk menangani masalah yang dihadapi keluarga diantaranya adalah art therapy, CBT, dan psikoedukasi.

Berdasarkan fenomena tersebut maka peneliti tertarik untuk melakukan penelitian tentang efektivitas intervensi psikoedukasi terhadap tingkat kecemasan keluarga dalam merawat klien skizofrenia.

\section{METODE PENELITIAN}

Rancangan penelitian yang digunakan pada penelitian ini adalah quasi eksperiment pre and post with control group. Populasi dalam penelitian ini adalah seluruh keluarga yang merawat pasien skizofrenia yang ada di Puskesmas Melong Asih
Kota Cimahi sebanyak 75 orang. Data ini didapatkan dari pelaporan program kesehatan jiwa Puskesmas Melong Asih tahun 2015. Teknik pengambilan sampel yang digunakan pada penelitian ini adalah Non Probability Sampling dengan metoda Consecutive Sampling. Kemudian dilakukan skrining untuk memenuhi kriteria inklusi dan eklusi. Berdasarkan penjelasan dari Walsh (2010) dan Raudhoh (2013) bahwa bahwa psikoedukasi dapat dilaksanakan secara kelompok maka sampel yang digunakan sebagai partisipan dalam penelitian ini adalah 6-12 orang. Hal ini merujuk pada penjelasan Herkov (2012) dan Gavino (2013) bahwa group therapy efektif dilakukan pada kelompok kecil yang beranggotakan sebanyak 6-12 orang.

Berdasarkan penjelasan tersebut, maka sampel dalam penelitian ini diambil sebanyak 12 responden untuk kelompok intervensi dan 12 responden untuk kelompok kontrol. Keseluruhan sampel yang diambil adalah 24 responden.

\section{HASIL PENELITIAN}

Sebagian besar $(75 \%)$ berjenis kelamin perempuan. Usia responden pada kelompok kontrol sebagian besar responden $(58,3 \%)$ berusia $46-$ 55 (lansia awal) dan data pendidikan menunjukkan sebagian besar responden pada kelompok intervensi (58\%) berpendidikan SMA. Data pekerjaan untuk kedua kelompok menunjukkan hampir seluruh responden $(83,3 \%)$ tidak bekerja (IRT), sedangkan data lama rawat klien menunjukkan pada kelompok kontrol hampir setengah responden $(41,7 \%)$ telah merawat klien selama 
4 tahun. Data dari hubungan keluarga

besar responden $(66,7 \%)$ klien pada kelompok intervensi sebagian sebagai anak.

Tabel 2. Distribusi karakteristik responden pada kelompok intervensi dan kelompok kontrol di wilayah Puskesmas Melong Asih.

\begin{tabular}{|c|c|c|c|c|c|}
\hline \multirow{2}{*}{ Karakteristik } & & \multicolumn{2}{|c|}{ Kelompok Intervensi } & \multicolumn{2}{|c|}{ Kelompok Kontrol } \\
\hline & & Jumlah & $\%$ & Jumlah & $\%$ \\
\hline \multirow[t]{2}{*}{ Jenis kelamin } & Laki-laki & 3 & 25 & 3 & 25 \\
\hline & Perempuan & 9 & 75 & 9 & 75 \\
\hline \multirow[t]{6}{*}{ Usia } & $\begin{array}{lll}\text { Usia } & 36 & -45\end{array}$ & 2 & 16,7 & 4 & 33,3 \\
\hline & (Dewasa Akhir) & & & & \\
\hline & 46-55 (lansia awal) & 2 & 16,7 & 7 & 58,3 \\
\hline & 55-65 (lansia akhir) & & & & \\
\hline & $>65$ (manula) & 4 & 33,3 & 1 & 8,3 \\
\hline & & 4 & 33,3 & 0 & 0 \\
\hline \multirow[t]{4}{*}{ Pendidikan } & & 2 & 16,7 & 2 & 16,7 \\
\hline & SMP & 3 & 25 & 6 & 50 \\
\hline & SMA & 7 & 58 & 4 & 33,3 \\
\hline & PT & 0 & 0 & 0 & 0 \\
\hline \multirow[t]{2}{*}{ Pekerjaan } & Rekeria & 2 & 16,7 & 2 & 16,7 \\
\hline & Tidak bekerja & 10 & 83,3 & 10 & 83,3 \\
\hline \multirow[t]{9}{*}{ Lama Rawat } & 2 tahun & 3 & 25 & 1 & 8,3 \\
\hline & 3 tahun & 1 & 8,3 & 4 & 33,3 \\
\hline & 4 tahun & 1 & 8,3 & 5 & 41,7 \\
\hline & 5 tahun & 1 & 83 & 2 & 16,7 \\
\hline & 6 tahun & 1 & 8,3 & 0 & 0 \\
\hline & 7 tahun & 1 & 8,3 & 0 & 0 \\
\hline & 8 tahun & 3 & 25 & 0 & 0 \\
\hline & 9 tahun & 1 & 8,3 & 0 & 0 \\
\hline & 10 tahun & 1 & 8,3 & 0 & 0 \\
\hline Hubungan & Suami & 1 & 8,3 & 0 & 0 \\
\hline \multirow[t]{4}{*}{ Keluarga } & Istri & 3 & 25 & 2 & 16,7 \\
\hline & Anak & 6 & 50 & 8 & 66,7 \\
\hline & Kakak & 1 & 8,3 & 1 & 8,3 \\
\hline & Adik & 1 & 8,3 & 1 & 83 \\
\hline
\end{tabular}


Tabel 3. Tingkat kecemasan keluarga dalam merawat klien skizofrenia pada kelompok intervensi sebelum dan sesudah dilakukan intervensi psikoedukasi

\begin{tabular}{|l|l|l|l|l|l|}
\hline \multicolumn{2}{|l|}{ Sebelum } & Sesudah \\
\hline $\begin{array}{l}\text { Tingkat } \\
\text { Kecemasan }\end{array}$ & Frekuensi & $\%$ & $\begin{array}{l}\text { Tingkat } \\
\text { Kecemasan }\end{array}$ & Frekuensi & $\%$ \\
\hline Sedang & 8 & 66,7 & Ringan & 5 & 41,7 \\
Berat & 4 & 33,3 & Sedang & 7 & 58,3 \\
\hline Total & 12 & 100 & Total & 12 & 100 \\
\hline
\end{tabular}

Tabel 3. menunjukkan data bahwa sebagian besar responden $(66,7 \%)$ berada pada skor kecemasan sedang pada kelompok intervensi sebelum dilakukan intervensi dan sebagian besar responden $(58,3 \%)$ berada pada tingkat kecemasan sedang setelah dilakukan intervensi. Sehingga simptom kecemasan yang dimunculkan tergolong sedang dan tidak terlalu mengganggu fungsi dari kegiatan keseharian yang bersangkutan.

Tabel 4. Tingkat kecemasan keluarga dalam merawat klien skizofrenia pada kelompok kontrol sebelum dan sesudah intervensi psikoedukasi

\begin{tabular}{|l|l|l|l|l|l|}
\hline Sebelum & Frekuensi & $\%$ & Sesudah & Tingkat \\
Tingkat & & & Kecemasan & & \\
Kecemasan & & 91,7 & Sedang & 11 & 91,7 \\
Sedang & 11 & 8,3 & Berat & 1 & 8,3 \\
Berat & 1 & 100 & Total & 12 & 100 \\
\hline Total & 12 & & & \\
\hline
\end{tabular}

Tabel 4. menunjukkan bahwa tingkat kecemasan keluarga sebelum intervensi dan sesudah intervensi pada kelompok kontrol hampir seluruh responden $(91,7 \%)$ berada pada tingkat kecemasan sedang, yang berarti responden pada kelompok kontrol mengalami kecemasan sedang, namun kedaan ini tidak mengakibatkan gangguan yang berarti pada aktivitas mereka.

Tabel 5. Perbedaan tingkat kecemasan keluarga dalam merawat klien skizofrenia pada kelompok intervensi sebelum dan setelah dilakukan intervensi psikoedukasi

\begin{tabular}{lllll}
\hline Kelompok & Rata-rata & t-hitung & t-tabel & P \\
\hline Pre Intervensi & 57,00 & 9,636 & 2,22814 & 0,000 \\
Post Intervensi & 46,00 & & & \\
\hline
\end{tabular}

Tabel 5 di atas, menunjukkan ratarata nilai pre-intervensi kelompok intervensi sebesar 57,00 dan rata-rata nilai post-intervensi sebesar 46,00 sehingga mengalami penurunan tingkat kecemasan sebesar 11,00. Didapatkan juga $\mathrm{t}$ hitung $>\mathrm{t}$ tabel pada taraf signifikansi $5 \%(9,639>$ 2,22814) dan mempunyai nilai $\mathrm{p}<$ 0,05 yang berarti dapat disimpulkan 
terdapat penurunan tingkat kelompok intervensi. kecemasan secara signifikan pada

Tabel 6. Perbedaan tingkat kecemasan keluarga dalam merawat klien skizofrenia pada kelompok kontrol sebelum dan setelah intervensi psikoedukasi

\begin{tabular}{lllll}
\hline Kelompok & Rata-rata & t-hitung & t-tabel & P \\
\hline Pre Intervensi & 50,83 & $-4,874$ & 2,22814 & 0,000 \\
Post Intervensi & 54,67 & & & \\
\hline
\end{tabular}

Tabel 6 di atas, menunjukkan ratarata nilai pre-intervensi kelompok kontrol sebesar 50,83 dan rata-rata nilai post-intervensi sebesar 54,67 sehingga mengalami peningkatan tingkat kecemasan sebesar 3,84. Didapatkan juga $\mathrm{t}$ hitung $<\mathrm{t}$ tabel pada taraf signifikansi $5 \%(-4,874<$ $2,22814)$ dan mempunyai nilai $\mathrm{p}<$
0,05 yang berarti dapat disimpulkan terdapat peningkatan tingkat kecemasan secara signifikan pada kelompok kontrol. Dari hasil tersebut dapat diprediksi bahwa jika tidak ada tindakan/intervensi psikoedukasi maka kecemasan keluarga akan lebih tinggi.

Tabel 7. Perbedaan tingkat kecemasan keluarga dalam merawat klien skizofrenia antara kelompok intervensi dan kelompok kontrol sebelum dan setelah intervensi.

\begin{tabular}{|l|l|l|l|l|l|}
\hline Sebelum Intervensi & \multicolumn{4}{l|}{ Setelah Intervensi } \\
\hline Kelompok & Rata-rata & P & Kelompok & Rata-rata & P \\
\hline Intervensi & 57,00 & 0,008 & Intervensi & 48,9167 & 0,007 \\
\hline Kontrol & 50,83 & & Kontrol & 54,6667 & \\
\hline
\end{tabular}

Tabel 7 menunjukkan rata-rata kelompok intervensi sebelum intervensi sebesar 57,00 dan rata-rata kelompok kontrol sebesar 50,83, sehingga dapat disimpulkan bahwa rata-rata kecemasan intervensi lebih 6,1667 lebih besar dibandingkan dengan kelompok kontrol. Dari tabel tersebut diketahui nilai signifikansinya kurang dari 0,05 ( $\mathrm{p}-$ value $=0,008<0,05)$. Dapat disimpulkan bahwa terdapat perbedaan tingkat kecemasan secara signifikan pada kelompok intervensi dan kelompok kontrol. Sedangkan setelah dilakukan intervensi Ringkasan uji $\mathrm{t}$ post-intervensi diketahui rata-rata kelompok intervensi sebesar 48,9167 dan ratarata kelompok kontrol sebesar
54,6667, sehingga dapat disimpulkan bahwa rata-rata tingkat kecemasan kelompok intervensi lebih kecil 5,75 dibandingkan dengan kelompok kontrol. Dari tabel tersebut diketahui nilai signifikansinya kurang dari 0,05 $(\mathrm{p}=0,007<0,05)$. Dapat disimpulkan bahwa terdapat perbedaan tingkat kecemasan secara signifikan pada kelompok intervensi dan kelompok kontrol.

\section{PEMBAHASAN}

Psikoedukasi merupakan suatu tindakan yang diberikan kepada individu atau orang tua untuk memperkuat strategi koping atau suatu cara khusus dalam mengatasi permasalahan psikologis yang 
dialami oleh seseorang (Mottaghipour \& Bickerton, 2005). Kecemasan adalah suatu keresahan, perasaan ketidaknyamanan yang disertai respon autonomis individu juga adanya kekhawatiran yang disebabkan oleh antisipasi terhadap bahaya (Wilkinson, 2007).

Menurut Hawari (2009) tanda dan gejala kecemasan pada setiap orang bervariasi. Keluhan yang sering dikemukakan oleh responden pada penelitian ini, saat mengalami kecemasan secara umum antara lain gejala psikologis, gangguan pola tidur, gangguan konsentrasi dan gangguan somatik. Kecemasan dapat diekspresikan secara langsung melalui perubahan fisiologis dan perilaku dan secara tidak langsung melalui timbulnya gejala atau mekanisme koping sebagai upaya untuk melawan timbulnya kecemasan (Kaplan \& Sadock, 2007).

Hasil penelitian diperoleh rata-rata kecemasan Keluarga sebelum dilakukan intervensi adalah 57 dan rata-rata sesudah diberikan intervensi adalah 46. Keluarga yang memiliki anggota keluarga dengan skizofrenia akan mengalami kecemasan akibat perubahan biopsikososial, dimana Keluarga harus mampu beradaptasi atau menyesuaikan dengan menerima keadaan yang dihadapinya, sehingga Keluarga akan mampu melakukan tindakan yang tepat dalam mengatasi permasalahannya. Menurut Roy (1999) setiap orang memahami bagaimana seseorang mempunyai batas kemampuan untuk beradaptasi, dimana kemampuan adaptasi manusia berbeda-beda antara yang satu dengan yang lainnya.
Hasil analisa perbedaan tingkat kecemasan sebelum dilakukan intervensi pada kelompok kontrol dan intervensi dengan menggunakan uji-t menunjukkan adanya perbedaan tingkat kecemasan yang berarti. Faktor yang menyebabkan perbedaan ini adalah bervariasinya skor yang muncul responden pada tiap kelompok. Penggunaan matching sample sulit diterapkan karena responden yang didapatkan terlalu heterogen, namun beberapa terdapat beberapa kesamaan karakteristik responden diantaranya jenis kelamin responden sebagian besar adalah perempuan, dan hampir seluruhnya responden tidak bekerja (IRT).

Menurut penelitian yang dilakukan oleh Truzi, et al (2012) mengenai perbedaan gender terhadap kecemasan, hasil penelitian menunjukkan bahwa caregiver perempuan lebih tinggi mengalami kecemasan. Perbedaan ini mungkin karena stereotip peran gender, dimana laki-laki tampak lebih kecil kemungkinan untuk mengungkapkan perasaan negatif daripada perempuan. Hal ini didukung oleh penelitian Hubbell dan Hubbell (2002) yang menyatakan bahwa caregiver laki-laki lebih berfikir positif dibandingkan perempuan dalam merawat klien Alzaimer.

Karakteristik usia responden didapatkan sebanyak $33,3 \%$ berada pada usia 55-65 dan > 65 tahun, pada usia tersebut seseorang sudah matang dalam berpikir karena pengalamannya.Peneliti sulit menemukan referensi baru yang membahas pengaruh perbedaan usia terhadap kecemasan. Namun hal tersebut sesuai dengan pendapat Maramis (1990) yang menyebutkan 
bahwa semakin rendah umur dan pendidikan seseorang maka semakin tinggi kecemasan yang dialami seseorang.

Karakteristik berikutnya yang dapat mempengaruhi tingkat kecemasan Keluarga adalah tingkat pendidikan. Semakin tinggi tingkat pendidikan, maka tingkat pengetahuan juga lebih banyak sehingga dapat berdampak pada sikap dan perilaku mereka yang positif (Wawan \& Dewi, 2010). Dapat disimpulkan jika semakin tinggi tingkat pendidikan Keluarga maka semakin tinggi perilaku positif yang ditimbulkan dalam merawat klien skizofrenia.

Menurut penelitian Gupta et al (2015) mengemukakan bahwa tidak ada hubungan antara lama perawatan dengan psychological well-being atau kesejahteraan psikologis pada caregiver (keluarga) pasien skizofrenia artinya keluarga dapat menerima kondisi klien dan tidak terpengaruh mengalami kecemasan walaupun mereka menjadi perawat penderita gangguan jiwa. Sejalan dengan penelitian Fitri dan Kartinah (2012) di Rumah Sakit Jiwa Daerah Surakarta menunjukkan bahwa meskipun keluarga merawat pasien dan membutuhkan waktu yang lama, tetapi keluarga tetap menunjukkan sikap positif sehingga tidak mengalami cemas, sikap menerima keadaan atau kondisi pasien merupakan suatu strategi preventif untuk mengurangi stres dan dampak negatifnya.

Savira (2015) dalam penelitiannya mengemukakan bahwa faktor yang membuat keluarga tetap mau merawat klien adalah ikatan keluarga/hubungan keluarga.
Terhubung dengan ikatan keluarga mau tak mau caregiver tetap akan merawat anggota keluarga yang menderita skizofrenia. Adanya dukungan dari orang-orang sekitar menjadikan caregiver lebih kuat, sehingga mampu dalam menjalankan perannya. Keluarga menyerahkan segala sesuatunya pada Tuhan dengan harapan memperoleh kemudahan selama merawat klien, meski merawat klien disertai masalah keluarga dapat mengambil hikmah atas apa yang dihadapinya. Sedangkan menurut penelitian yang dilakukan oleh Peni (2014) ditemukan bahwa 33,3\% tingkat kecemasan keluarga cenderung meningkat pada kondisi cemas berat pada hubungan keluarga sebagai anak. Seorang anak mempunyai ikatan batin serta hubungan yang lebih erat, karena ada pertalian darah secara langsung.

Hasil analisa tingkat kecemasan pada kelompok intervensi sebelum dilakukan intervensi psikoedukasi sebagian besar $(66,7 \%)$ mengalami tingkat kecemasan sedang tingkat kecemasan setelah dilakukan intervensi sebagian besar $(58,3 \%)$ tingkat kecemasan responden berada pada kecemasan sedang dan hampir setengah responden $(41,7 \%)$ berada pada tingat kecemasan ringan. Hal ini menunjukkan bahwa adanya kesesuaian dengan hipotesis, bahwa intervensi psikoedukasi efektif dilakukan untuk menurunkan tingkat kecemasan keluarga yang merawat klien skizofrenia. Penelitian yang mendukung adalah penelitian yang dilakukan Sharief, et al (2012) mengemukakan bahwa psikoedukasi yang dilakukan pada keluarga klien skizofrenia memberikan dampak positif dalam mengurangi kecemasan 
dan gejala klien setelah satu bulan intervensi.

Penelitian terapi psikoedukasi yang dilakukan pada keluarga klien skizofrenia masih terbatas pada pengaruhnya terhadap beban perawatan, emosi, dan manajemen perawatan klien. Intervensi psikoedukasi pada keluarga klien skizofrenia dari berbagai penelitian yang telah dilakukan berdampak positif terhadap masalah keluarga dalam merawat klien. Penelitian yang dilakukan oleh Sharif, et al (2012), Tanriverdi \& Ekinci (2012), Ozkan et al (2013) dan Fallahi, et al (2014) menyebutkan bahwa psikoedukasi efektif dalam meningkatkan kemampuan keluarga dalam merawat klien sehingga menurunkan angka kekambuhan dan dirawat, menurunkan kecemasan keluarga, menurunkan emosi dan depresi pada keluarga. Hal ini mendukung hasil penelitian bahwa psikoedukasi efektif dalam menurunkan tingkat kecemasan Keluarga secara signifikan dengan pvalue $=0,007$

Hasil penelitian ini juga sesuai dengan teori menurut Mottaghipur dan Bickerton (2005), psikoedukasi merupakan suatu tindakan yang dilakukan pada individu dan keluarga untuk memperkuat strategi koping atau cara khusus dalam menangani kesulitan perubahan mental. Ditunjukan dalam hasil penelitian ini bahwa presentasi kelompok intervensi mempunyai tingkat kecemasan lebih rendah dibandingkan dengan kelompok kontrol.

Intervensi psikoedukasi dilakukan sebanyak 5 sesi pada kelompok intervensi terhadap tingkat kecemasan. Setiap sesi dilakukan pengukuran tingkat kecemasan. Lama waktu proses pelaksanaan intervensi psikoedukasi tiap sesi memerlukan waktu yang berbedabeda. Sebagian sesuai dengan lama waktu yang direncanakan yaitu selama 35-45 menit. Tetapi responden membutuhkan waktu lebih lama dalam pemberian psikoedukasi yaitu sekitar 60 menit. Keluarga pada saat sesi tanya jawab banyak menanyakan tentang cara merawat dan pemberdayaan keluarga dalam merawat klien skizofrenia, sehingga peneliti harus menjelaskan hal tersebut sehingga membutuhkan waktu yang lebih lama dari waktu yang telah direncanakan.

Intervensi psikoedukasi dalam penelitian ini diberikan kepada responden melalui kegiatan pendidikan kesehatan tentang perawatan klien skizofrenia, manajemen stress, manajemen kecemasan, dan pemberdayaan keluarga. Manajemen stress dan cemas yang diberikan kepada responden, berupa pemberian latihan nafas dalam untuk mengatasi stress dan kecemasaan yang dialami oleh responden sebagai dampak dalam merawat klien dengan skizofrenia kemudian diberikan kesempatan latihan untuk mengeksplorasi perasaan stress dan cemas serta kesempatan untuk saling bertukar pikiran dan pengalaman dengan responden lain. Perubahan peningkatan pengetahuan responden nampak dalam setiap sesi digambarkan dengan adanya penurunan skor kecemasan yang dialami oleh responden. Hal ini sejalan dengan penelitian Atkin \& Ahmad (2008) bahwa dukungan 
profesional yang tepat dapat membantu mengurangi stress dan memfasilitasi koping dengan memberikan informasi dan dukungan emosional.

Pemberian informasi yang lengkap tentang apa yang ingin diketahui oleh Keluarga dapat mengupayakan cara untuk menghindari pencetus terjadinya kecemasan. Pemberian dorongan dan motivasi pada keluarga dapat mengurangi perasaan cemas dan khawatir keluarga klien. Hal ini sesuai dengan teori Hawari (2006) yang mengemukakan pemberian intervensi psikoedukasi dapat menurunkan kecemasan dengan memberikan informasi yang mungkin dulu telah didapatkan dalam merawat klien dan bagaimana cara untuk menghadapi klien pada waktu sebelum klien mengalami gangguan jiwa, dalam masa pertumbuhan dimasa anak dan remaja sehingga dapat mengatasi perilaku dan keadaan emosi klien di rumah.

\section{KESIMPULAN}

Berdasarkan hasil penelitian dan interpretasi maka pada penelitian ini dapat disimpulkan bahwa intervensi psikoedukasi efektif dalam menurunkan tingkat kecemasan keluarga dalam merawat klien skizofrenia. Efektivitas ini nampak pada perbedaan tingkat kecemasan keluarga dalam merawat klien skizofrenia pada kelompok intervensi sebelum dan setelah dilakukan intervesi psikoedukasi terdapat terdapat penurunan tingkat kecemasan secara signifikan, perbedaan tingkat kecemasan keluarga dalam merawat klien skizofrenia pada kelompok kontrol sebelum dan setelah dilakukan intervensi mengalami peningkatan kecemasan, sehingga dapat diprediksi bahwa jika tidak dilakukan intervensi pada keluarga dalam merawat klient skizofrenia akan terjadi peningkatan keceamasan.

Perbedaan tingkat kecemasan keluarga dalam merawat klien skizofrenia antara kelompok intervensi dan kelompok kontrol sebelum intervensi, terdapat perbedaan yang signifikan, dan terdapat perbedaan tingkat kecemasan keluarga dalam merawat klien skizofrenia antara kelompok intervensi dan kelompok kontrol setelah intervensi. Pada kelompok intervensi tingkat kecemasan semakin menurun, namun pada kelompok kontrol terjadi peningkatan tingkat kecemasan.

\section{DAFTAR PUSTAKA}

Atkin, K \& Ahmad, W. I. (2008). Family caregiving and chronic illness : how parents cope with a child with a sikcle cell disorder or thalasemia. Center for research in primary care. Nuffield institute for health. University of leeds. UK.

Braga, R.J, Mendlowicz, M.V, Marrocos, R.P. 2010. Anxiety disorders in Family with schizophrenia: prevalence and impact on the subjective quality of life. Psychiatry Research Departement, Fluminense Federal University, Niteroi, Brazil. 
Fallahi, K., Sheikhoma, M., Rahgozar, M., \& Sodagari, F. (2014). The effect of group psychoeducation program on family burden in caregivers of Iranian patients with schizophrenia. Journal of Psychiatric Mental Health Nursing. Jun: 5): 438-46.

Fitri, S.L dan Kartinah. (2012). Hubungan Persepsi Keluarga Tentang Gangguan Jiwa Dengan Sikap Keluarga Kepada Anggota Keluarga Yang Mengalami Gangguan Jiwa Di Rumah Sakit Jiwa Daerah Surakarta.Publikasi Ilmiah. 05(3) ; p.1-7.

Goode, W. (2007). Sosiologi Keluarga (Cet. Ke-7). Jakarta: PT Bumi Aksara.

Gupta, S., Isherwood, G., Jones, K., and Van Impe, K. (2015). Assessing health status in informal schizophrenia caregivers compared with health status in noncaregivers and caregivers of other conditions. BMC Psychiatry: 162.

Hawari. (2001). Pendekatan pada Gangguan Jiwa Skizofrenia. FKUI: Jakarta.

Hubbell, L \& Hubbell, K. (2002). The burnout risk for male caregivers in providing care to spouses afflicated with Alzaimer's disease. Journal of Health and Human Services Administration; Summer; 25.
Kalpan \& Saddock . (2007), Synopsis of Pshyciatry Science ClinicalPsychiatry Baltimore: Williams \&Wilkins.

Keliat, et all. (2011). Manajemen Kasus Gangguan Jiwa CMHN. Jakarta ; EGC

Maramis, W. F. (1990). Catatan Ilmu Kedokteran Jiwa. Surabaya : Airlangga University press.

Mottaghipour, A. \& Bickerton, A. (2005). The pyramid of family care: A frame work for family involment with adult mental health service. Australian eJournal for the Advancementof Mental Health,vol. 4, Issue 3.

Peni, T. (2014). Kecemasan Keluarga Pasien Ruang ICU Rumah Sakit Daerah Sidoarjo. Jurnal Hospital Majapahit. Volume 6 No. 1.

Raudhoh, S. (2013). Psikoedukasi: Inetrvensi Rehabilitasi dan Prevensi. Bandung: Fakultas Psikologi.

Reinhard, S. C., Given, B., Petlick, N. H., \& Bemis, A. (2008). Supporting family care giver in providing care. Patient Safety and Quality: An Evidence Based Hanndbook for Nurses, Vol. 1.

Roy, S. C. (1999), The Roy Adaptation Model : The Defenitive Statement, California : Appleton \& Lange. 
Savira, S. I. (2015). Pengalaman Family Caregiver Orang Dengan Skizofrenia. Fakultas Ilmu Pendidikan. Unesa. Volume 03 Nomor 2.

Sharif, F., Haygan, M., Mani, A. (2012). Effect of a psychoeducational ntervention for family members on caregiver burdens and psychiatric symptoms in patients with schizophrenia in Shiraz, Iran.. BMC Psychiatry. BioMed Cenral Ltd.

Takai, M., Takahashi, M., Iwamitsu, Y., Oishi, S., \& Miyaoka, H. (2011). Subjective experiences of family caregivers of patien with dimentia as predictive factor of quality of life. Psychogeriatrics. 11:98-104.

Tanriverdi, D. \& Ekinci, M. (2012). Effect psychoeducation intervention has on the caregiving burden of caregivers for schizophrenic patiens in Turkey. PubMed: Int J Nurs Pract, Jun: 18(3): $128-8$

Truzi, A., Valente, L., Ulstein, I., Engelhardt, E., Laks, J., \& Engedal, K. (2012). Burnout in familial caregivers of patients with dimensia. Journal of the Brazilian Psychiatric Association. Elsevier Editora Ltda. All right reserved.

Videbeck, S., L. (2011). Psychiatric Mental health Nursing. Philadelphia ; Lippincott Williams \& Wilkins.
Walsh, J.F. (2010). Psychoeducations in Mental Health. Chicago: Lyceum.

Wawan, A \& Dewi, M. (2010). Teori dan Pengukuran Pengetahuan, Sikap dan Perilaku Manusia. Yogyakarta: Nuha Medika.

Whitfield, C., Dubeb, S., Felitti, V. \& Anda, R. (2005). Adverse childhood experiences and hallucinations. Child Abuse \& Neglect, 29, 797-810.

WHO, (2014). The world Health Report 2014 ; Mental Health New Understanding, New Hope.

Wilkinson, J. M. (2007). Buku saku diagnose keperawatan dengan intervensi NIC NOC. Jakarta: EGC. 